\title{
Tomato Graft Union Failure Is Associated with Alterations in Tissue Development and the Onset of Cell Wall Defense Responses
}

\author{
Carlos Frey ${ }^{1, *(\mathbb{D}}$, Rafael Álvarez $\left.{ }^{2} \mathbb{(}\right)$, Antonio Encina ${ }^{1}\left(\mathbb{D}\right.$ and José Luis Acebes ${ }^{1}[\mathbb{C}$ \\ 1 Área de Fisiología Vegetal, Departamento de Ingeniería y Ciencias Agrarias, Facultad de Ciencias Biológicas y \\ Ambientales, Universidad de León, 24071 León, Spain; a.encina@unileon.es (A.E.); \\ jl.acebes@unileon.es (J.L.A.) \\ 2 Área de Biología Celular, Departamento de Biología Molecular, Facultad de Ciencias Biológicas y \\ Ambientales, Universidad de León, 24071 León, Spain; ralvn@unileon.es \\ * Correspondence: cfred@unileon.es
}

check for updates

Citation: Frey, C.; Álvarez, R.; Encina, A.; Acebes, J.L. Tomato Graft Union Failure Is Associated with Alterations in Tissue Development and the Onset of Cell Wall Defense Responses. Agronomy 2021, 11, 1197. https://doi.org/10.3390/ agronomy11061197

Academic Editor: Alberto

San Bautista

Received: 19 May 2021

Accepted: 8 June 2021

Published: 11 June 2021

Publisher's Note: MDPI stays neutral with regard to jurisdictional claims in published maps and institutional affiliations.

Copyright: (c) 2021 by the authors. Licensee MDPI, Basel, Switzerland. This article is an open access article distributed under the terms and conditions of the Creative Commons Attribution (CC BY) license (https:/ / creativecommons.org/licenses/by/ $4.0 /)$.

\begin{abstract}
Grafting is a technique applied to a considerable number of crops, with tomato standing out. However, this technique is limited by the obtaining of unfunctional grafts, which decrease the success rate and therefore the benefits achieved. The aim of this work was to analyze the failure in intraspecific grafting of tomato plants, focusing on tissue development, cell wall defense reactions, and the distribution of starch and soluble sugars at the graft junction. The success rate in autografts was higher than that of homografts and heterografts. Unfunctional homografts and heterografts showed similar responses: absence of vascular reconnections and lack of adhesion between scion and rootstock, even though callus cell clusters and differentiation of new vasculature were produced. The scions of unfunctional grafts accumulated more starch and soluble sugars than the rootstocks, showing a strong asymmetry in the response. In addition, three types of deposits were observed in the cell walls of unfunctional grafts: lignin, suberin, and callose, with the combined accumulation of more than one of them being frequent, particularly lignin and suberin. These deposits apparently prevent adhesion and seem to be a major cause of graft failure.
\end{abstract}

Keywords: callose; grafting; lignin; starch; suberin; sugars

\section{Introduction}

Tomato (Solanum lycopersicum L.) is one of the most important and popular crops around the world, being the sixth largest crop in terms of yield ( $\mathrm{kg} / \mathrm{ha}$ ) [1]. This indicates the high economic importance of this vegetable; in fact, economically speaking, tomato is the most important vegetable crop worldwide [2], partly due to the contribution of improved grafting techniques. Grafting began to spread at the beginning of the 1960s and now it has become a common practice for tomato cultivation $[3,4]$, to such an extent that at the beginning of $2010,50 \%$ and $75 \%$ of the tomato plants in France and the Netherlands, respectively, were grafted [4].

The grafting process is complex, involving a sequential set of changes, from molecular to tissue levels, at the graft interface during graft healing [5,6]. During grafting, there is an abrupt interruption in the exchange of substances between rootstock and scion, resulting in an asymmetry that affects the tissue development and physiological status of both graft partners. The success of the graft will depend on an orderly process of regeneration involving: (1) tissue damage response, cell adhesion, and callus formation; (2) tissue cohesion and vascular cell differentiation; and, finally, (3) vascular reconnection [7-14]. The success of the graft is also dependent on factors such as grafting method, graft healing conditions (especially adequate conditions of humidity and temperature), previous physiological status of the plants, etc. $[7,10,14]$. The failure and/or unfunctionally of grafts 
can be high in certain combinations or conditions, resulting in low success ratios that are negative to farmers and producers via the increasing of graft prizes, grafting effort, and even graft quality. Moreover, new and potentially beneficial graft combinations are not explored due to compatibility barriers. Some incompatibility causes are: (a) genetic distance $[7,15,16]$, (b) physiological and/or anatomical difficulties [14,17], (c) toxic compounds transference [18,19], (d) inadequate cell-to-cell recognition [20], and (e) triggering of stress responses [20-23].

Understanding the reasons for graft failure, and especially the failure caused by low compatibility, will allow for the development of new strategies aimed to improve the graft success ratio. However, many causes of incompatibility and failure have yet to be understood. To the best of our knowledge, the contribution of cell wall defense reactions at the cut edges, together with sugar-starch distribution between rootstock and scion, in unfunctional combinations are poorly studied and further research can shed light on the causes of graft failure. Therefore, this work aimed to explore the failure and unfunctionally of tomato intraspecific grafts, focusing on cell wall defense reactions (such as defensive lignification, suberification, and callose deposition), soluble sugars and starch distribution, and tissue development at the graft interface.

\section{Materials and Methods}

\subsection{Plant Cultivation}

The seeds of commercial varieties "Minibel" (Mascarel-Semillas S.L.) and "Marmande VR" (Semillas Batlle S.A.) were sown in individual recipients with $170 \pm 10 \mathrm{~mL}$ of peat substrate and placed on plastic trays, as previously reported [12]. Hoagland nutritive solution was used for watering and the substrate was maintained near to the field capacity. The seedlings were grown in a culture chamber with $16 \mathrm{~h}$ of light daily (390-730 nm, enriched in 630-660 $\mathrm{nm}$ and $440-460 \mathrm{~nm} ; \approx 35 \mu \mathrm{mol} / \mathrm{m}^{2} / \mathrm{s}$ ) at $23 \pm 1{ }^{\circ} \mathrm{C}$.

\subsection{Grafting Method}

The grafts were made when the stems under the cotyledon leaves reached 3-4 mm thickness (approximately one month after sowing). Different categories of grafts were made: autografts (rootstock and scion from the same "Minibel" plant, abbrev. C), homografts ("Minibel" scion of one plant over "Minibel" rootstock of another plant, CC), and heterografts ("Minibel" scion over "Marmande VR" rootstock, abbrev. CM, and "Marmande VR" scion over "Minibel" rootstock, MC). Non-grafted plants were used as controls. Scions and rootstocks were obtained by making a transverse cut below the cotyledon leaves. Cut faces were then joined and the junctions wrapped in Parafilm $®$ and protected using Toogoo ${ }^{\circledR}$ silicon clips (Figures $1 \mathrm{~b}$ and $2 \mathrm{a}$ ). The grafted plants were kept for 7 days in $\mathrm{a}$ humid atmosphere $(\approx 90 \% \mathrm{RH})$, which was gradually ventilated afterward.

\subsection{Sample Collection}

A total of 79 grafts were made for histological analyses. From them, 12 were C, 13 were CC, 25 were MC, and 29 were CM. Approximately half of the grafts of each type were collected 10 days after grafting (DAG) and the rest 20 DAG. The graft success ratio was determined 10 and 20 DAG by visual inspection. Grafts with a withered appearances and without a consolidated union were selected and processed as unfunctional grafts. 


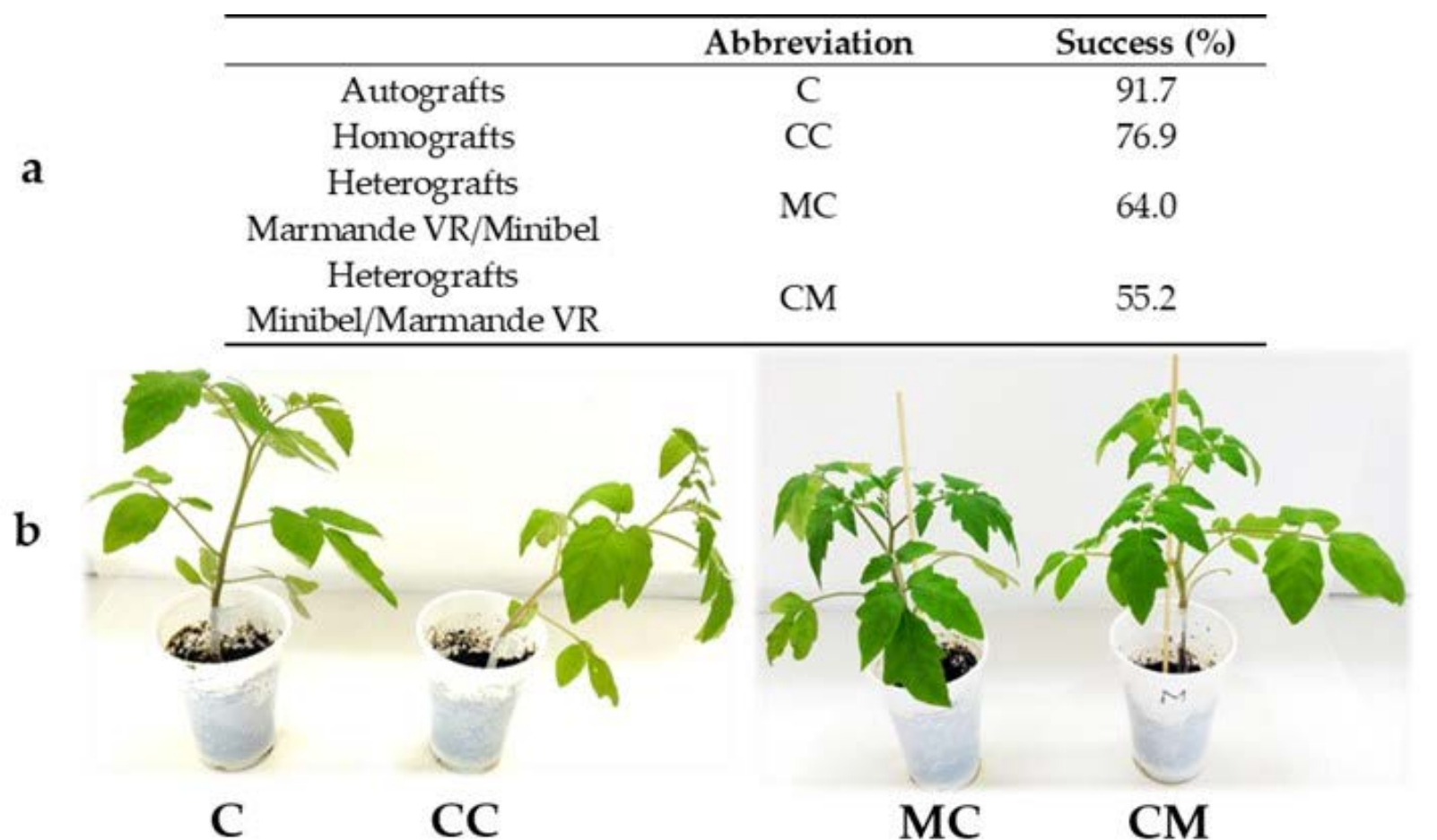

Figure 1. (a) Success percentage for each type of scion/rootstock combination 20 days after grafting (DAG). C (Minibel autografts), CC (Minibel homografts), MC heterografts (Marmande VR scion over Minibel rootstock heterografts), CM heterografts (Minibel scion over Marmande VR rootstock heterografts) ( $\mathrm{N}=12,13,25$, and 29 for $\mathrm{C}, \mathrm{CC}, \mathrm{MC}$, and CM, respectively). (b) Appearance of the representative types of functional grafts 10 DAG.

\subsection{Fixation, Inclusion and Cuts}

Segments of stems containing grafts were fixed in formalin-acetic acid-alcohol (FAA) (24-48 h). After fixation, samples were dehydrated in ascending grades of ethanol (30 min in $70 \%, 60 \mathrm{~min}$ in $96 \%, 75 \mathrm{~min}$ in $100 \%$ ) and placed in isoamyl acetate (75 $\mathrm{min}$ in $100 \%$ ). Afterward, they were embedded in paraffin wax for $6 \mathrm{~h}$ at $60{ }^{\circ} \mathrm{C}$. Paraffin blocks were sectioned into $12 \mu \mathrm{m}$ slices by using a rotatory microtome (Leitz-Wetzlar 1512, Leitz, Milton Keynes, Bucks, UK). All samples were embedded in paraffin wax, except those samples which were free-hand sectioned and used for Sudan III staining.

\subsection{Histological Techniques}

The $12 \mu \mathrm{m}$ tissue sections were deparaffinized with xylene, rehydrated and stained with four different staining methods (safranin-fast green, hematoxylin-eosin, Lugol, and phloroglucinol). In addition, two fluorescence probes (calcofluor and sirofluor) were used. Afterward, the tissue sections were dehydrated in ascending grades of ethanol, dewaxed in xylene, and mounted with Entellan synthetic resin. Tissue sections observed under epifluorescence were not stained. A Nikon E600 microscope was used for bright-field observations and also for fluorescence probes using an UV-2 filter (330-380 nm). Sections stained with Sudan III were observed with a Nikon SMZ 1500 stereoscope (Nikon, Tokyo, Japan). The histological methods are summarized in Table 1. 

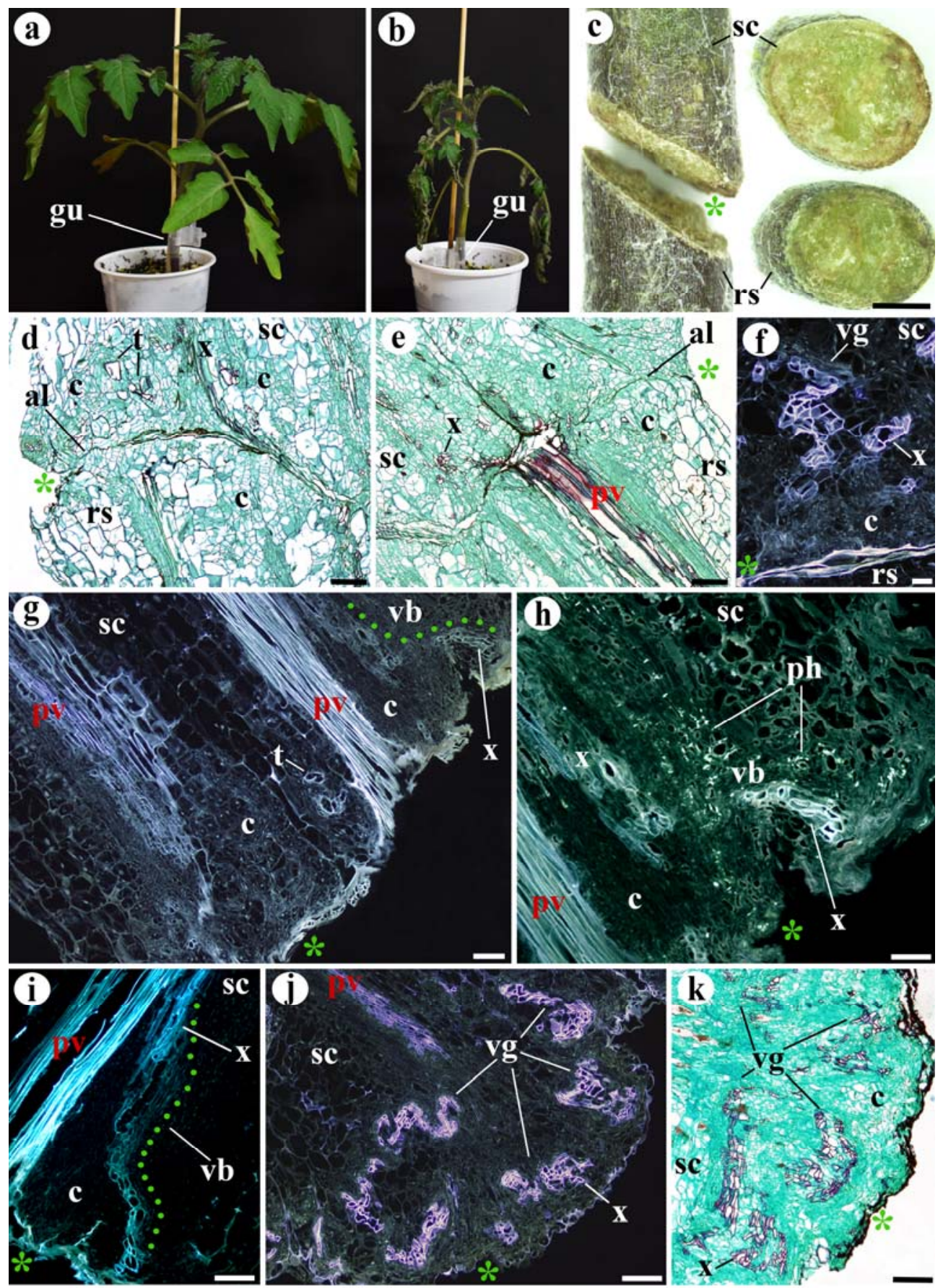

Figure 2. Morphological and structural features of unfunctional tomato grafts (a-i) 10 DAG and (j,k) 20 DAG. (a) Functional graft for comparison. (b) Unfunctional graft, note the wilted appearance. (c) Unfunctional graft under stereoscope; left, longitudinal view; right, transverse view; see the sealed appearance of the junction areas of scion ( $s c$ ) and rootstock ( $r s$ ). (d,e) Longitudinal sections of unfunctional grafts, note the presence of small adhesion areas and the absence of vascular reconnections. (f) Longitudinal section of unfunctional graft, see the undifferentiated callus cells (c) and vascular groupings $(v g) .(\mathrm{g}-\mathbf{i})$ Longitudinal sections of unfunctional grafts, note the undifferentiated callus cells $(c)$, the vascular branches $(v b$, green points) arising from the pre-existing vasculature $(p v)$, and the transdifferentiated $(p h)$ parenchyma cells $(t)$ in $(\mathbf{g})$. $(\mathbf{j}, \mathbf{k})$ Longitudinal sections of unfunctional grafts, note the large callus tissue (c) and vascular groupings (vg). (d,e,k) Safranin-fast green staining. (h) Sirofluor staining. (d,e,k) Bright-field images. (f-j) Epifluorescence microscope images. Asterisk, cut edge; $a l$, adhesion line; $c$, callus; $g u$, graft union; $p v$, pre-existing vasculature; $r s$, rootstock; $s c$, scion; $t$, transdifferentiating cells; $v b$, vascular branch; $v g$, vascular groupings; $x$, xylem or xylem cells. Scale bars: $(\mathbf{c})=2 \mathrm{~mm} ;(\mathbf{d}-\mathbf{i})=100 \mu \mathrm{m} ;(\mathbf{j}, \mathbf{k})=300 \mu \mathrm{m}$. 
Table 1. Histological methods for preparation of slides and microscope observations.

\begin{tabular}{cccc}
\hline Staining & Mounting & Microscope & Target \\
\hline Safranin-fast Green & Entellan & Bright-field & General staining \\
Hematoxylin-eosin & Entellan & Bright-field & General staining \\
Lugol & No & Bright-field & Starch \\
Sirofluor & No & Fluorescence & Lignin \\
Phloroglucinol (Wiesner) & No & Bright-field & Cellulose \\
Calcofluor & No & Fluorescence & Suberin and hydrophobic compounds \\
Sudan III & No & Stereoscope & Autofluorescence \\
\hline
\end{tabular}

\subsection{Amyloplast Frequency Estimation}

Image analysis of amyloplast frequency was carried out using Image $1.53 \mathrm{e}$ software. Five histological images of longitudinal sections of the scion and rootstock at the graft junction or of non-grafted plants were analyzed and the number of amyloplasts of 15 representative cells was reported for each image.

\subsection{Soluble Sugars Extraction}

Stem segments $(10 \mathrm{~mm})$ containing the graft interface of 14 Minibel autografts $(C)$ at the same stage of development as those collected for histological techniques were used for sugar extraction. The segments were separated from the scion $(5 \mathrm{~mm})$ and rootstock $(5 \mathrm{~mm})$, then dried at $40{ }^{\circ} \mathrm{C}$ and weighed. Afterward, segments were homogenized with $70 \%$ ethanol and incubated for $24 \mathrm{~h}$ for soluble sugars extraction. The solution was centrifuged for $10 \mathrm{~min}$ at 12,500 rpm and the supernatant was collected as an ethanol-soluble sugars fraction. The residue was incubated for $24 \mathrm{~h}$ with a new $70 \%$ ethanol solution and then centrifuged. The supernatant was collected and added to the soluble sugars fraction.

\subsection{Sugar Determination}

Soluble sugars quantification was performed using the phenol-sulfuric acid method [24] and the results were expressed as glucose equivalents.

\subsection{Statistical Analysis}

All statistical analyses were performed using IBM SPSS Statistics v. 25 software (IBM, New York, NY, USA). The normality and homoscedasticity of the data series were tested using Kolmogorov-Smirnov's test and Levene's test, respectively. Differences among means were analyzed by using an ANOVA test $(p \leq 0.05)$ when normally distributed and homoscedastic data were compared. A non-parametric Kruskal-Wallis H-test or Mann-Whitney U-test $(p \leq 0.05)$ was used when data were not normally distributed or homoscedastic.

\section{Results and Discussion}

The frequency of graft failure changed in relation to the different types of combinations. Results obtained showed that the genetic distance between the varieties could be enough to explain success ratio differences. Although all types of combinations had a success rate greater than $50 \%$, the success ratio in heterografts was lower than in homografts or autografts (Figure 1). All unfunctional grafts presented similar aspects, regardless of the type of combination. The scions showed a wilted appearance and lower vigorousness (Figure $2 \mathrm{a}, \mathrm{b}$ ) presumably due to the water stress via xylem water column breakage. In addition, about half of graft junctions showed a partially sealed appearance. None of the unfunctional grafts formed a union callus (Figure 2c). 


\subsection{Tissue Development in Unfunctional Grafts}

At the histological level, tissue distribution in one-month-old, non-grafted tomato stems matched the classic eustele model with open collateral vascular bundles and the presence of an interfascicular vasculature to form a complete vascular ring (Figure S1). From inside to outside: the medullar parenchyma, xylem, vascular meristem, phloem, cortical parenchyma, and epidermis were identified.

Functional grafts 10 DAG showed callus cell clusters (undifferentiated cells), adhesion between scions and rootstocks, and vascular reconnections (Figure S2), all of which were generating the union callus (Figure S2a-d). These findings are compatible with the previous works about tomato graft histology [12,25-27] and the general hypothesis of callus generation in graft unions [14]. Additionally, they shed light on graft tissues development, especially with regard to how vascular connections are made.

Histological analysis of both unfunctional homografts and heterografts showed a similar response. The main feature of unfunctional grafts was that they did not present vascular reconnections (Figure 2), and the tissues of the scion and rootstock generally did not adhere; only small areas of adhesion were detected in some grafts (Figure 2d,e).

However, callus cell clusters and differentiation of new vasculature were observed in the unfunctional grafts. Both phenomena were identified 10 DAG (Figure 2d-i), and new vasculature increased considerably by 20 DAG (Figure 2j,k). These findings could indicate that the processes of cell dedifferentiation and proliferation, as well as vascular differentiation, occur in grafts regardless of their functionality. Related to this, sometimes functional grafts present a small callus instead of a prominent one [28], and also non-grafted injured stems present a noticeable wound-induced callus [13]. Therefore, the presence of a prominent callus at the junction zone is not necessarily indicative of graft functionality.

The formation of callus cell clusters and new vasculature were located close to the pre-existing vasculature (Figure $2 \mathrm{~d}, \mathrm{e}, \mathrm{g}-\mathrm{i}$ ), just like it was identified in functional tomato grafts [12]. The primary origin of callus cell clusters is most likely the pre-existing vasculature. In fact, the WIND1 transcription factor increases its expression after wounding in the cells close to the wound and provokes cell dedifferentiation and cell division through the activation of a signaling pathway in which cytokinins participate [29-31]. Furthermore, WIND1 is also strongly expressed in vascular meristematic tissues [13,29].

The new vascular cells arose as: (1) branches of the pre-existing vasculature (Figure 2g-i) (most prevalent), (2) vascular groupings (disorganized xylem) dispersed inside the callus (Figure 2f,j,k) (also known as anastomoses [32]), and (3) parenchyma cell transdifferentiating into xylem vessels, metaplasia events (Figure 2d,g). Furthermore, the most distal extremes of the pre-existing vasculature remained inert, playing no active part in the response to grafting (Figure 2e,g-i). These three methods of vasculature development have also been described in functional tomato grafts [12], suggesting that vascular regeneration depends strongly on the pre-existing vasculature. Auxins play a key role in the new vascular tissue formation [33-35]. The polar flux of auxins along the scion vasculature and its cell channelization might provoke the formation of the branches that arise from the pre-existing vasculature [36,37].

\subsection{Asymmetry of Rootstock and Scion Responses in Unfunctional Grafts}

In unfunctional grafts, an accumulation of circulating sugars and auxins is expected to occur in the scion side of the graft junction due to scion/rootstock disconnection, resulting in responses as those described in Figure 3a. Sugars and auxins must be translocated from scion to rootstock in order to enhance and consolidate the response in the latter [11,14]. 


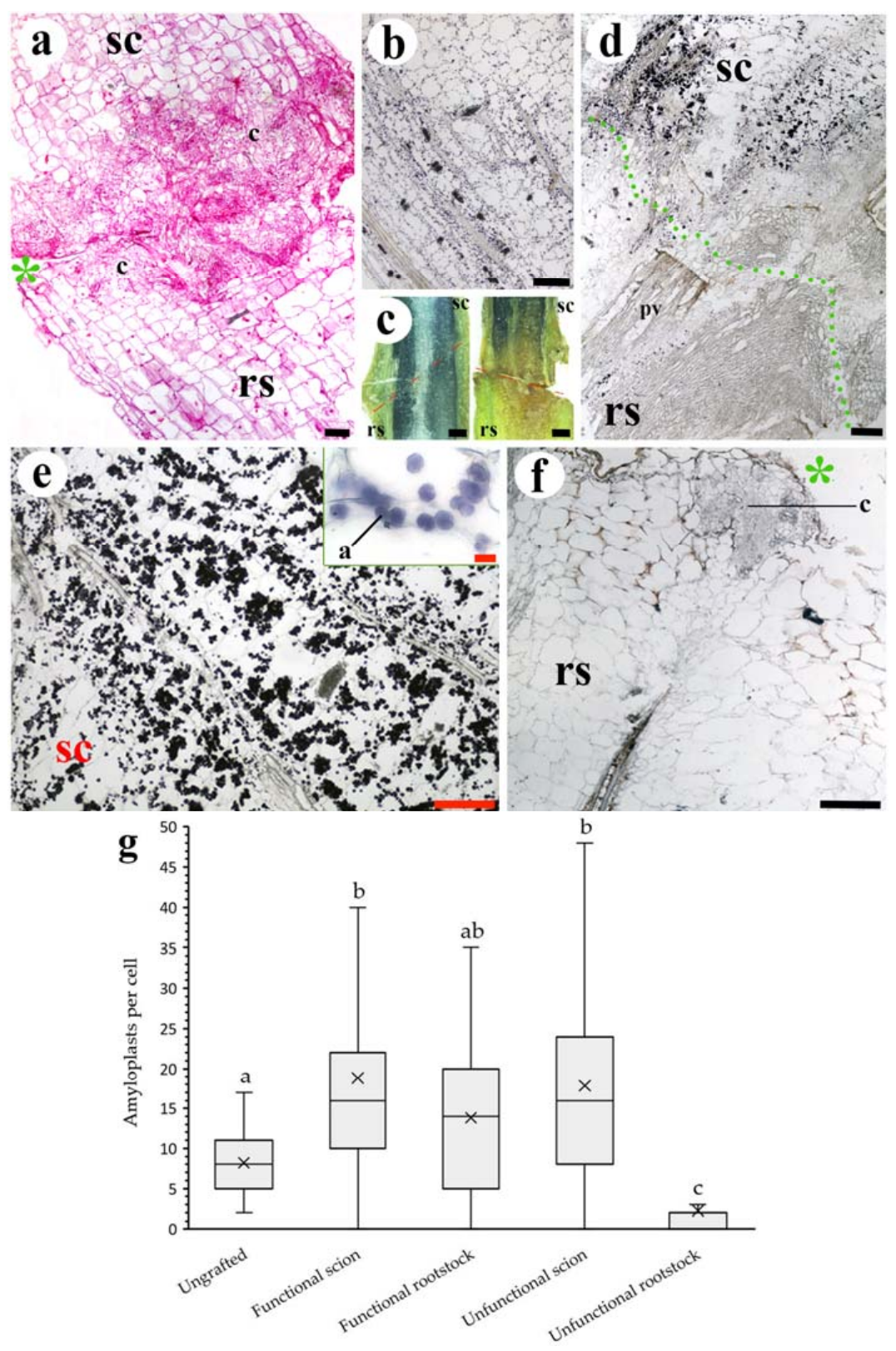

Figure 3. Asymmetrical responses in scions/rootstocks (a) and uneven amyloplast distribution (b-g) in unfunctional grafts. (a) Longitudinal section of 10 DAG unfunctional graft, note the differences in the callus (c) development between scion and rootstock. (b) Longitudinal section of non-grafted tomato stem. See the presence of amyloplasts (dark points) in different tissues of the stem. (c) Free-hand longitudinal section of 10 DAG functional (left side) and unfunctional (right side) grafts observed under a stereoscope. The dark tone indicates amyloplast presence. See the approximately symmetric distribution in the functional graft and the asymmetry in the unfunctional graft. (d) Longitudinal section of 20 DAG unfunctional graft. Note the broken adhesion line (green points) and the asymmetric distribution of amyloplasts between the scion and rootstock. (e,f) Longitudinal section of 10 DAG unfunctional graft scion and rootstock, respectively. See the amyloplast (a) detail in (e). (g) Average number of amyloplasts per cell of sampling image analysis of non-grafted and functional and unfunctional 10 DAG grafts $(\mathrm{N}=75$ cells). Different letters indicate significant differences at the $p$-value $<0.05$ level after Kruskal-Wallis H-test. (a) Hematoxylin-eosin staining. (b,d-f) Lugol staining. (a,b,d-f) Bright-field images. Asterisk, cut edge; $a$, amyloplast; $c$, callus; $p v$, pre-existing vasculature; $r s$, rootstock; $s c$, scion. Scale bars: $(\mathbf{a}, \mathbf{b}, \mathbf{d}-\mathbf{f})=200 \mu \mathrm{m}(10 \mu \mathrm{m}$ in (e) detail); (c) $=1 \mathrm{~mm}$. 
Uneven Distribution of Starch and Soluble Sugars Content

Amyloplasts (starch) distribution showed a marked asymmetry between unfunctional scions and rootstocks; a high number of amyloplasts were observed in the scion tissues (over the amount found in non-grafted stems), whereas in the unfunctional rootstocks they were hardly detected (Figure $3 \mathrm{~b}-\mathrm{g}$ ). In addition, the soluble sugars content of unfunctional scions was significantly higher than that of unfunctional rootstocks. As a consequence, the rootstock-to-scion sugar ratio shifted below 0.2 in unfunctional grafts (Figure 4), highlighting the asymmetry of sugar accumulation in unfunctional grafts. On the other hand, functional grafts showed similar amounts of starch and soluble sugars between scions and rootstocks. Soluble sugars and starch are correlated variables, and their changes could be considered in equivalency showing an important relevance.

a

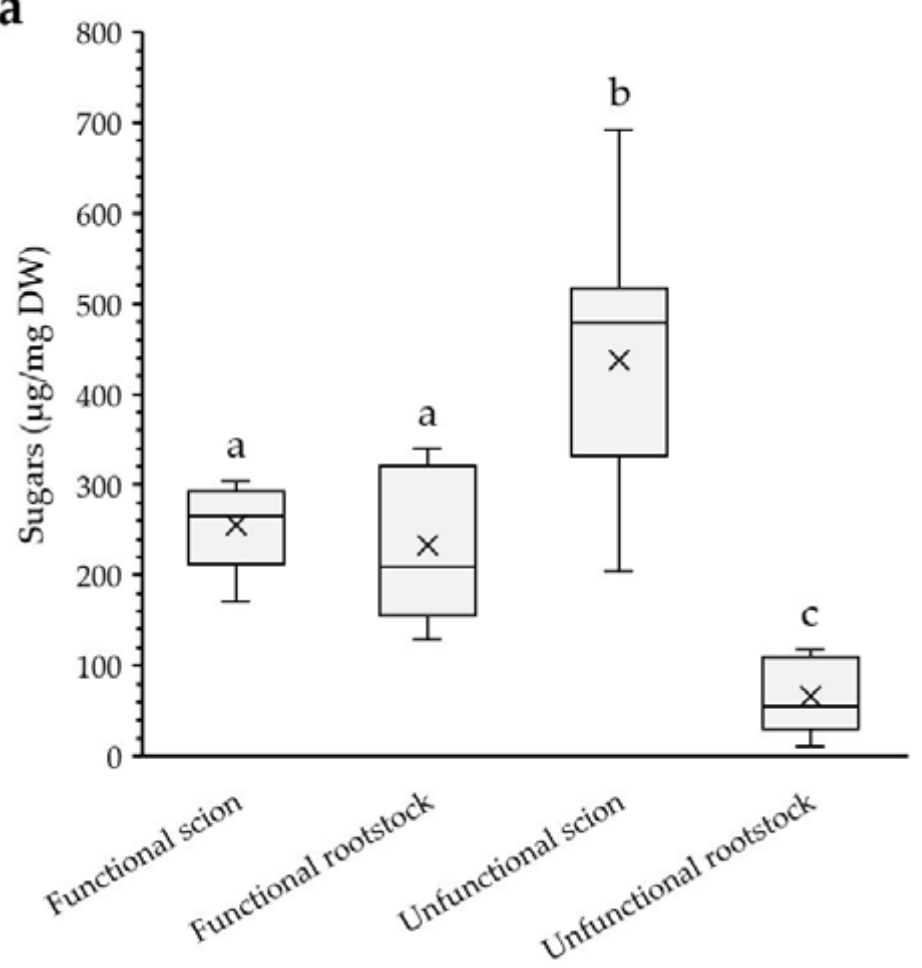

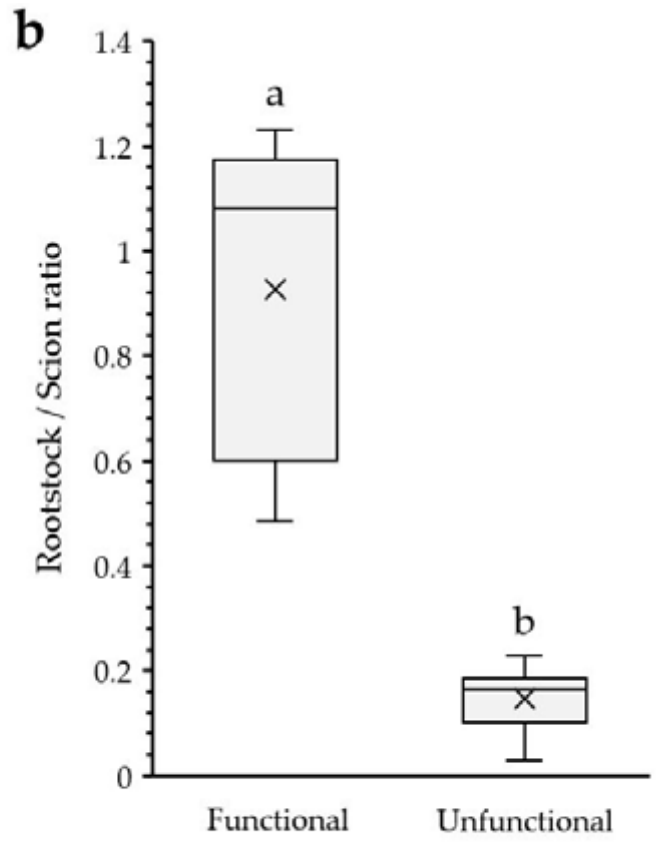

Figure 4. (a) Ethanol soluble sugars content of functional and unfunctional scions and rootstocks. DW, dry weight. (b) Rootstock/scion ethanol soluble sugars ratio in functional and unfunctional grafts. Ratio value $=1$ implies same sugar content between rootstock and scion. Different letters indicate significant differences at the $p$-value $<0.05$ level after ANOVA test in (a) and Mann-Whitney U-test in (b). $\mathrm{N}=5$ and 9 for functional and unfunctional grafts, respectively.

The differential pattern in soluble sugars and starch accumulation in unfunctional grafts could be due to scion tissues near the cutting edge becoming a strong sink after cutting because tissue development processes require a considerable amount of energy. While this occurs in the scion, the rootstock tissues near the junction zone do not receive sugars because the phloem transport is interrupted and the sugar reserves are being depleted. On the contrary, in functional grafts, vascular reconnection occurs, phloem transport is restored, and, presumably, the rootstock receives sugars some days after grafting. The asymmetry in starch content has been previously identified in rose unfunctional grafts [38].

At the initial stage of graft healing, the accumulation and depletion of sugar and auxins in the scion and rootstock, respectively, provoke the first responses in the tissues [39]. Auxins with sugars present could trigger the vascular differentiation process $[33,40,41]$. For this reason, at least auxins and sugars must be translocated to the rootstock to trigger vascular differentiation $[13,29]$. The availability of sugars seems important to graft healing 
and their translocation is key for rootstock vasculature development. In fact, low starch content in rootstocks has been proposed as a symptom of future failure [42].

\subsection{Cell Wall Responses}

If the adhesion is successful, the adhered tissues start a cell wall remodeling process (Figure S2) and new symplastic connections are formed between scion and rootstock tissues [25,43]. However, in the unfunctional grafts, the cells at the cut edges presented different types of deposits in their cell walls. Three defensive compounds were identified in these deposits: suberin (Figure 5), lignin, and callose (Figure 6), ordered from highest to lowest abundance. These deposits occupied a variable number of cell layers in the external zone of the cut edge. Suberin deposition usually involved a high number of cell layers (more than 5) (Figure 5b-g), while callose deposition involved a few layers or even few cells (Figure 6f,g). Lignification of the cut edges did not follow a clear pattern. However, the cell walls placed the closest to the cut edges were often lignified (Figure 6a). Mixed deposits were frequent, with the simultaneous occurrence of lignin and suberin being most prevalent (Figure $6 \mathrm{a}-\mathrm{c}$ ). These deposits prevented adhesion between the scion and rootstock and appeared to be the main factor causing the lack of functionality in this study.

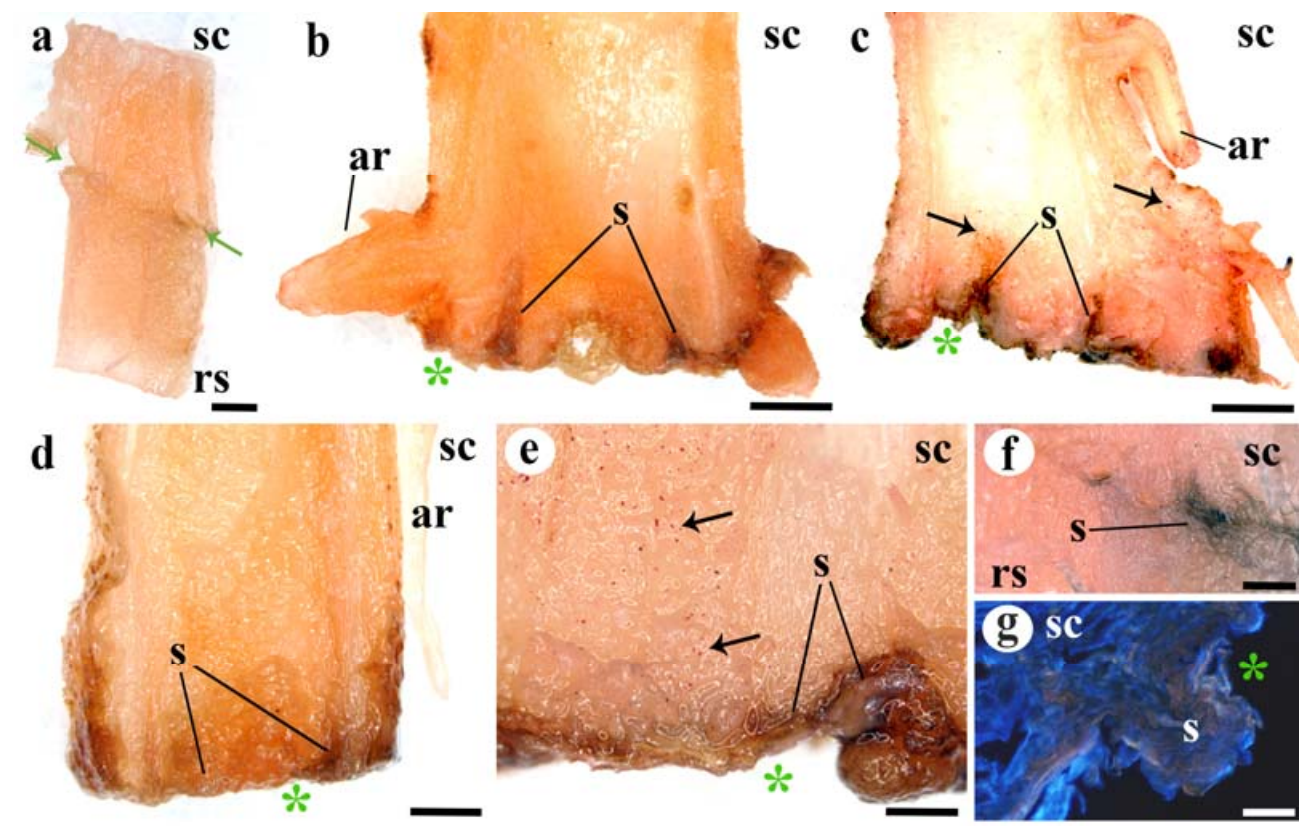

Figure 5. Deposition of suberin in longitudinal graft sections. (a) Functional graft, note the absence of dark brown color at the adhesion line. $(\mathbf{b}, \mathbf{c})$ Twenty DAG unfunctional grafts, see the dark tones indicating suberin (s) deposition at the cut edges and cells near the cut. Black arrows indicate lipid inclusions. (d) Ten DAG unfunctional graft, note the suberin (s) deposition at the cut side. (e) Twenty DAG unfunctional graft detail. Note the layer of suberin (s) deposits and the lipid inclusions (red points) indicated by black arrows. (f) Functional graft line of adhesion, see the accumulation of suberin in a small area of non-adhesion. (g) Twenty DAG unfunctional graft detail, see the suberin (s) protuberance, identified by the brow color, at the cut edge. (a-f) Sudan III staining. (g) Calcofluor staining. (a-f) Stereoscope images. (g) Epifluorescence microscope images. Asterisk, cut edge; ar, adventitious root; $r s$, rootstock; $s$, suberin; $s c$, scion. Arrows indicate lipid inclusions. Scale bars: $(\mathbf{a}-\mathbf{d})=1 \mathrm{~mm} ;(\mathbf{e}, \mathbf{f})=500 \mu \mathrm{m} ;(\mathbf{g})=200 \mu \mathrm{m}$. 

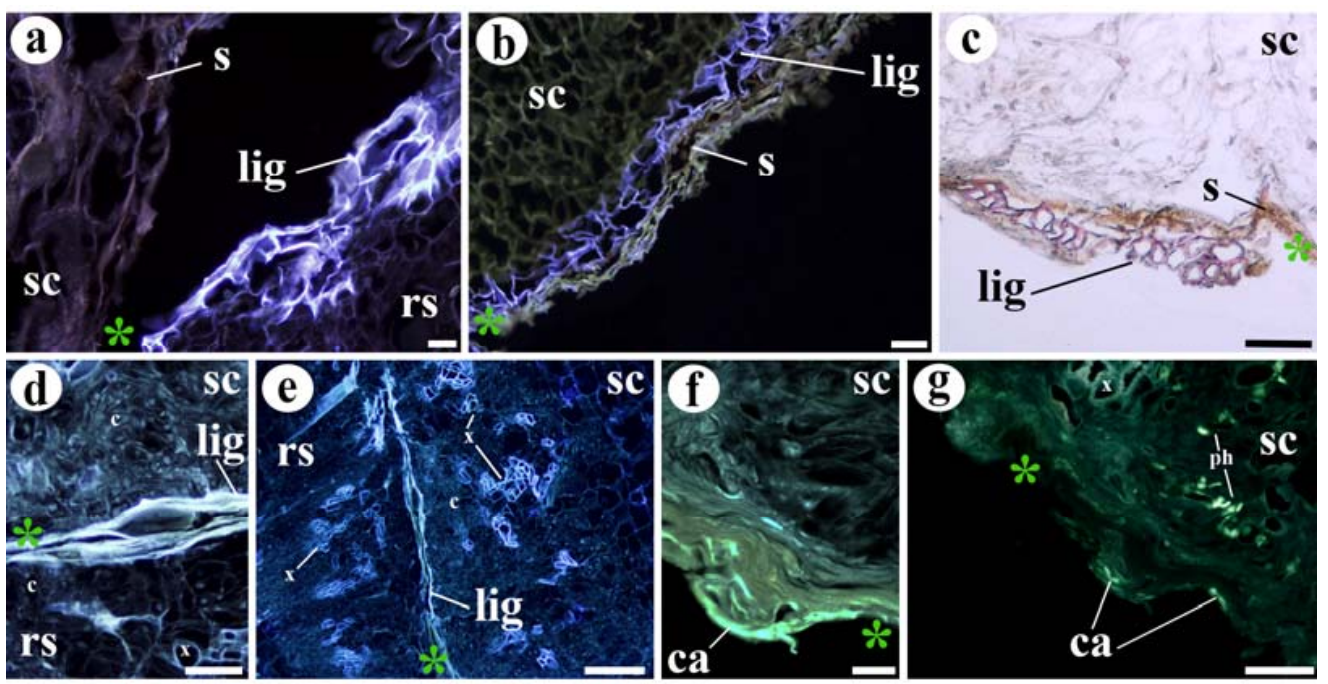

Figure 6. Deposition of lignin and callose at cut edges of unfunctional grafts. (a) Ten DAG unfunctional graft section. Note the presence of suberin $(s)$ and lignin (lig) deposition in the scion and rootstock, respectively. (b) Twenty DAG unfunctional graft cut edge. See the double deposition of lignin (inner layer) (lig) and suberin (s) (outer layer). (c) Twenty DAG unfunctional graft, note the layer of lignified cells (lig) and also the suberin (s) layer. (d,e) Ten DAG unfunctional graft section, note the layer of lignification (lig) that prevents the adhesion. (f,g) Ten DAG unfunctional graft cut edge, note the callose $(c a)$ deposition, green/yellow fluorescence. See also the fluorescence in the phloem ( $p h$ ) callose plates. (c) Phloroglucinol (Wiesner) staining. (f,g) Sirofluor staining. (a,b,d-g) Epifluorescence microscope images. (c) Bright-field image. Asterisk, cut edge; $c$, callus; ca, callose; lig, lignin; $p h$, phloem; $r s$, rootstock; $s$, suberin; $s c$, scion. Scale bars: $(\mathbf{a}, \mathbf{b}, \mathbf{f})=50 \mu \mathrm{m} ;(\mathbf{c}, \mathbf{d}, \mathbf{g})=100 \mu \mathrm{m}$; (e) $=500 \mu \mathrm{m}$.

Table 2 summarizes the above observations.

Table 2. Semiquantitative comparative profiling between functional grafts, unfunctional scions, and unfunctional rootstocks for different parameters 20 DAG.

\begin{tabular}{|c|c|c|c|c|c|c|c|c|}
\hline & $\begin{array}{l}\text { Union } \\
\text { Callus }\end{array}$ & $\begin{array}{l}\text { Callus Cell } \\
\text { Clusters }\end{array}$ & $\begin{array}{c}\text { Vascular } \\
\text { Differentiation }\end{array}$ & Adhesion & $\begin{array}{c}\text { Vascular } \\
\text { Reconnection }\end{array}$ & $\begin{array}{l}\text { Amyloplast } \\
\text { Frequency }\end{array}$ & $\begin{array}{l}\text { Soluble } \\
\text { Sugars }\end{array}$ & $\begin{array}{c}\text { Cell Wall } \\
\text { Defensive } \\
\text { Deposits }\end{array}$ \\
\hline Functional graft & +++ & +++ & +++ & +++ & +++ & + & + & - \\
\hline Unfunctional scion & - & ++ & ++ & $-/ \pm$ & - & +++ & +++ & +++ \\
\hline $\begin{array}{l}\text { Unfunctional } \\
\text { rootstock }\end{array}$ & - & + & + & $-/ \pm$ & - & \pm & \pm & ++ \\
\hline
\end{tabular}

$[+]$ presence; [-] absence; relative amounts indicated by number of symbol repetitions (subjective description).

The scion/rootstock cell adhesion is one of the first and essential steps during graft healing $[14,25]$. Adhesion appears to be a non-specific process. In fact, internodes of Solanum pennellii can "graft" weakly to a piece of dead wood [44]. However, the fusion between the tissues is specific and it is strongly controlled by cell-to-cell recognition [45]. An adequate response to the graft would unlock the onset of adhesion and fusion through modifications in the cell wall components, such as homogalacturonan (cell wall pectin) deposition, and further de-methyl-esterification [20,25,46,47], the XTH19 and XTH20 (xyloglucan endotransglycosylase/hydrolase) induction [48], the $\beta-1,4-$ glucanase induction [49], the expansins action [47], and the cell wall thinning that facilitates plasmodesmata formation $[20,50]$.

Our results suggest that the mechanism of graft adhesion and/or recognition failed in unfunctional grafts because of a hypersensitive cell wall defense reaction (Figure 7). When it occurs, graft-derived tissue damage would trigger a defense response [51] characterized by suberification, lignification, and callose deposition at the cut edges. It should be kept in 
mind that these three processes have been previously associated with wound or infection response and oxidative bursts in plants [52-58].

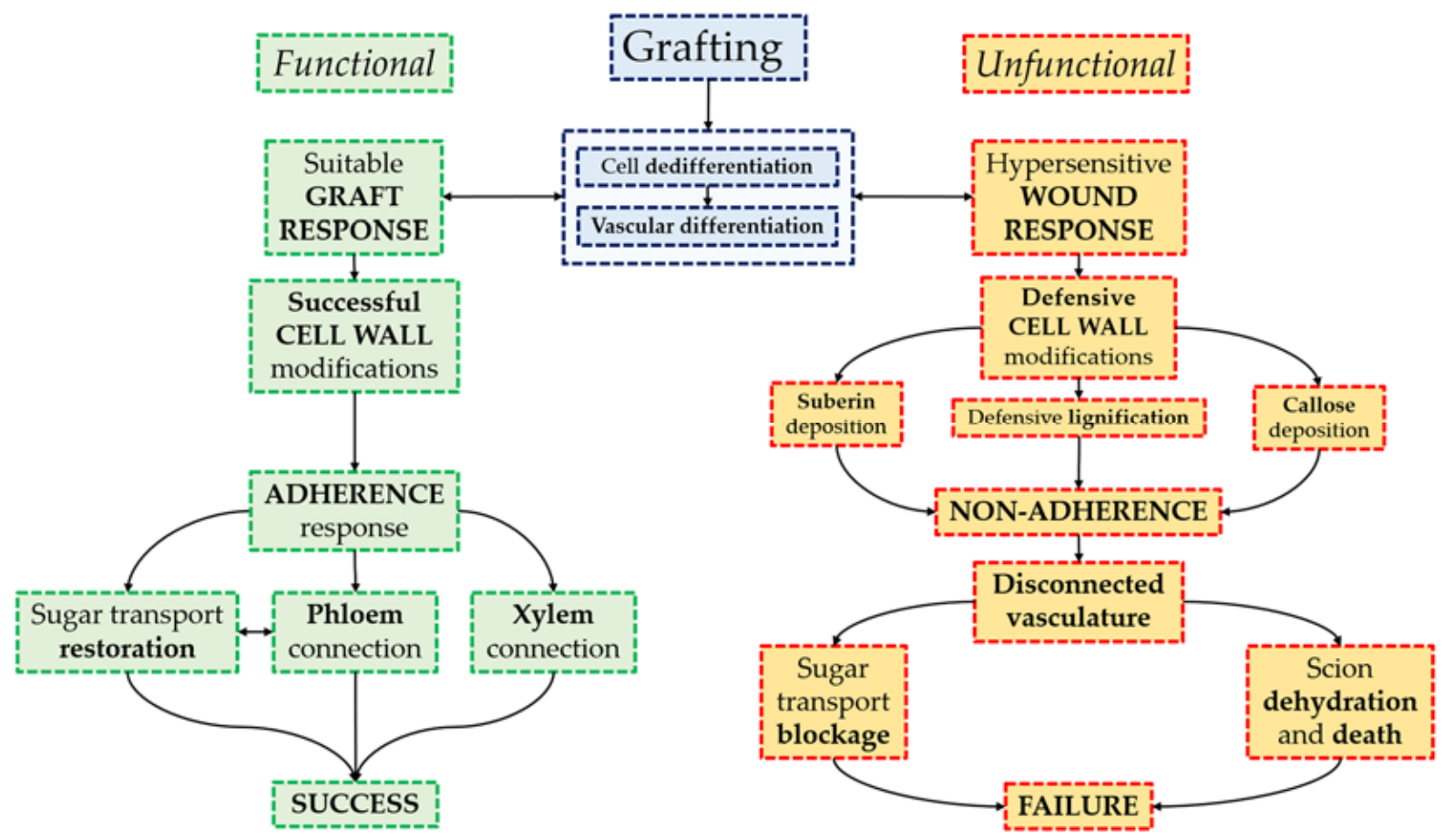

Figure 7. Summary diagram of graft healing with special focus on cell wall changes. The adhesion response determines graft success.

Therefore, our results point to triggering of hypersensitive cell wall defense reactions as a source of graft failure in tomato grafts. We hypothesize that the graft partners, especially the scion, respond intensely to the wound and deposit defensive cell wall materials such as suberin, lignin, and callose, which would prevent adhesion and lead to graft failure even though callus cell clustering and vascular differentiation would be occurring. In addition, it could be hypothesized that a major impact of the environmental conditions on grafting success is related to an adequate wound response, since it has been shown in tomato grafts that low temperatures $\left(15-20^{\circ} \mathrm{C}\right)$ enhance the grafting success ratio [59] and accelerate the vascular connection and healing process [60].

In conclusion, histological analysis of unfunctional tomato grafts showed: (a) the lack of vascular reconnections and adhesion between scion and rootstock, (b) a strong asymmetry in graft response as scions of unfunctional grafts accumulated more starch and soluble sugars than rootstocks, and (c) the accumulation of lignin, suberin, and callose as responses of defensive sealing, which apparently prevent adhesion and seem to be one of the main causes of graft failure.

New strategies based on the control of the defensive sealing responses could improve tomato grafting success yield. Moreover, as the defensive sealing responses are transversal in plants, the strategies could be applied to other crops.

Supplementary Materials: The following are available online at https:/ / www.mdpi.com/article/ 10.3390/agronomy11061197/s1, Figure S1: Histology of tomato stem, below the cotyledon leaves, one month after sowing. (a) Scheme of transversal section of tomato stem. (b) Transversal section of tomato stem, observe the next distribution from the inside to the outside: pith parenchyma (pp), xylem (x), vascular meristem (vm), phloem (ph), cortical parenchyma (cp) and epidermis (ep). Note the vascular ring. (c-e) Longitudinal sections of tomato stems. Note in (c) the typical colour of xylem conducting cells under UV-2 excitation, in (d) the crystalline inclusions remarked by red circles, in (d,e) a phloem fiber (fb) and in (e) the callose (ca) of phloem sieve plates and a group of 
amyloplasts (a). (f) Detail image of vascular tissue, observe the difference between tracheal cells (tch) and tracheid cells (td). (g) Detail of microcrystals (mc), observe the small size of each one. (d) Safranin-fast green. (e) Sirofluor. (b,c,e,f) Epifluorescence microscope. (d) Bright field microscope. (g) Polarisation microscope. $a$, amiloplast; $c a$, callose; $c p$, cortical parenchyma; $e p$, epidermis; $f b$, fiber; $m c$, microcrystals; $p h$, phloem; $p p$, pith parenchyma; $t c h$, trachea; $t d$, tracheid; $t$ i, trichome; $v m$, vascular meristem; $x$, xylem. Scale bars: $(b, c, f)=200 \mu \mathrm{m} ;(\mathrm{d}, \mathrm{e}, \mathrm{g})=100 \mu \mathrm{m}$. Figure S2: Histology of a functional tomato graft union 10 DAG. (a) Graft longitudinal section, note the adhesion between scion and rootstock and the consolidated vascular connections (VC) (b,c) Details of graft longitudinal section, observe the vascular connections (VC) between scion and rootstock and the pre-existing vasculature (pv) without connection. (d) Longitudinal section of vascular connection (VC), note how xylem (x) is continuous between scion and rootstock. (e) Longitudinal section of vascular connection (VC), observe especially how phloem (ph), distinguished by callose (ca) marking, is continuous. (f) Detail of vascular connection (VC). (g) Junction zone of graft union, note the adhesion line (al) between scion and rootstock. (h) Longitudinal section of graft union, birefringent structures are xylem cells, microcrystals and amyloplasts. (i) Callus cells (c) of graft union. (j) Detail of union zone, note the adhesion line (al) between graft parts. $(d, j)$ Safranin-fast green. (e) Sirofluor. (g,i) Haematoxylineosin. $(\mathrm{d}, \mathrm{g}, \mathrm{i}, \mathrm{j})$ Bright field microscope. (e,f) Epifluorescence microscope. (h) Polarisation microscope. White arrows indicate the graft junction. al, adhesion line; $c$, callus cells; $c a$, callose; $p h$, phloem; $p v$, pre-existing vasculature; $r s$, rootstock; $s c$, scion; $V C$, vascular connections; $x$, xylem. Scale bars: $(\mathrm{a}-\mathrm{c})=1 \mathrm{~mm} ;(\mathrm{d}, \mathrm{e})=200 \mu \mathrm{m} ;(\mathrm{f}-\mathrm{h}, \mathrm{j})=100 \mu \mathrm{m} ;(\mathrm{i})=50 \mu \mathrm{m}$.

Author Contributions: J.L.A. and A.E. conceived, designed, and supervised the research; R.Á. designed and supervised the sample handling and microscopy techniques; C.F. conducted the experiments, analyzed the data, and wrote the manuscript; J.L.A., R.Á. and A.E. contributed to analyze the data and supervised the manuscript. All authors have read and agreed to the published version of the manuscript.

Funding: This research was funded by the Universidad de León. C.F. acknowledges the PhD grant from the FPU program of the Spanish Science and Innovation Ministry (Ref. FPU18/04934).

Institutional Review Board Statement: Not applicable.

Informed Consent Statement: Not applicable.

Data Availability Statement: Not applicable.

Acknowledgments: The authors acknowledge the microscopy service of the Universidad de León, the equipment loan, María Yebra's and Antonio Sánchez's help and advice.

Conflicts of Interest: The authors declare no conflict of interest.

\section{References}

1. Food and Agriculture Organization of the United Nations. FAOSTAT Statistical Database (Crops). Available online: http: //www.fao.org/faostat/en/\#data/QC (accessed on 1 December 2020).

2. Bergougnoux, V. The history of tomato: From domestication to biopharming. Biotechnol. Adv. 2014, 32, 170-189. [CrossRef]

3. Singh, H.; Kumar, P.; Chaudhari, S.; Edelstein, M. Tomato grafting: A global perspective. HortScience 2017, 52, 1328-1336. [CrossRef]

4. Lee, J.-M.; Oda, M. Grafting of herbaceous vegetable and ornamental crops. In Horticultural Reviews; Janick, J., Ed.; John Wiley \& Sons: Oxford, UK, 2010; Volume 28, pp. 61-124.

5. Williams, B.; Ahsan, M.U.; Frank, M.H. Getting to the root of grafting-induced traits. Curr. Opin. Plant Biol. 2021, $59,101988$. [CrossRef]

6. Loupit, G.; Cookson, S.J. Identifying molecular markers of successful graft union formation and compatibility. Front. Plant Sci. 2020, 11, 610352. [CrossRef]

7. Hartmann, H.T.; Kester, D.E.; Davies, F.T.; Geneve, R.L. Hartmann \& Kester's Plant Propagation Principles and Practices, 9th ed.; Pearson: Harlow, UK, 2018; pp. 433-481.

8. Lindsay, D.W.; Yeoman, M.M.; Brown, R. An analysis of the development of the graft union in Lycopersicon esculentum. Ann. Bot. 1974, 38, 639-646. [CrossRef]

9. Moore, R.; Walker, D.B. Graft formation in Solanum pennellii (Solanaceae). Plant Cell Rep. 1984, 3, 172-175. [CrossRef]

10. Martínez-Ballesta, M.C.; Alcaraz-López, C.; Muries, B.; Mota-Cadenas, C.; Carvajal, M. Physiological aspects of rootstock-Scion interactions. Sci. Hortic. 2010, 127, 112-118. [CrossRef]

11. Nanda, A.K.; Melnyk, C.W. The role of plant hormones during grafting. J. Plant Res. 2018, 131, 49-58. [CrossRef] 
12. Frey, C.; Acebes, J.L.; Encina, A.; Álvarez, R. Histological changes associated with the graft union development in tomato. Plants 2020, 9, 1479. [CrossRef]

13. Melnyk, C.W.; Schuster, C.; Leyser, O.; Meyerowitz, E.M. A developmental framework for graft formation and vascular reconnection in Arabidopsis thaliana. Curr. Biol. 2015, 25, 1306-1318. [CrossRef]

14. Melnyk, C.W. Plant grafting: Insights into tissue regeneration. Regeneration 2017, 4, 3-14. [CrossRef] [PubMed]

15. Wulf, K.E.; Reid, J.B.; Foo, E. What drives interspecies graft union success? Exploring the role of phylogenetic relatedness and stem anatomy. Physiol. Plant. 2020, 170, 32-147. [CrossRef]

16. Tsaballa, A.; Xanthopoulou, A.; Madesis, P.; Tsaftaris, A.; Nianiou-Obeidat, I. Vegetable grafting from a molecular point of view: The involvement of epigenetics in rootstock-scion interaction. Front. Plant Sci. 2020, 11, 621999. [CrossRef] [PubMed]

17. Melnyk, C.W.; Meyerowitz, E.M. Plant grafting. Curr. Biol. 2015, 25, R183-R188. [CrossRef]

18. Goldschmidt, E.E. Plant grafting: New mechanisms, evolutionary implications. Front. Plant Sci. 2014, 5, 727. [CrossRef] [PubMed]

19. Moore, R. Studies of vegetative compatibility-Incompatibility in higher plants. V. A morphometric analysis of the development of a compatible and an incompatible graft. Can. J. Bot. 1982, 60, 2780-2787. [CrossRef]

20. Pina, A.; Errea, P.; Martens, H.J. Graft union formation and cell-to-cell communication via plasmodesmata incompatible and incompatible stem unions of Prunus spp. Sci. Hortic. 2012, 143, 144-150. [CrossRef]

21. Aloni, B.; Karni, L.; Deventurero, G.; Levin, Z.; Cohen, R.; Katzir, N.; Lotan-Pompan, M.; Edelstein, M.; Aktas, H.; Turhan, E.; et al. Physiological and biochemical changes at the rootstock-Scion interface in graft combinations between Cucurbita rootstocks and a melon scion. J. Hortic. Sci. Biotechnol. 2008, 83, 777-783. [CrossRef]

22. Irisarri, P.; Binczycki, P.; Errea, P.; Juel, H.; Pina, A. Oxidative stress associated with rootstock-scion interactions in pear / quince combinations during early stages of graft development. J. Plant Physiol. 2015, 176, 25-35. [CrossRef]

23. Baron, D.; Esteves Amaro, A.C.; Pina, A.; Ferreira, G. An overview of grafting re-establishment in woody fruit species. Sci. Hortic. 2019, 243, 84-91. [CrossRef]

24. Dubois, M.; Gilles, K.A.; Hamilton, J.K.; Rebers, P.A.; Smith, F. Colorimetric method for determination of sugars and related substances. Anal. Biochem. 1956, 28, 350-356. [CrossRef]

25. Jefree, C.E.; Yeoman, M.M. Development of intercellular connections between opposing cells in a graft union. New Phytol. 1983, 93, 491-509. [CrossRef]

26. Fan, J.; Yang, R.; Li, X.; Zhao, W.; Zhao, F.; Wang, S. The processes of graft union formation in tomato. Hortic. Environ. Biotechnol. 2015, 56, 569-574. [CrossRef]

27. Milewska-Hendel, A.; Polak, M.; Sala, K.; Zieleźnik-Rusinowska, P.; Gawecki, R.; Kurczyńska, E. Morpho-histological analysis of tomato (Solanum lycopersicum L.) plants after treatment with juglone. Acta Agrobot. 2017, 70, 1701. [CrossRef]

28. Yin, H.; Yan, B.; Sun, J.; Jia, P.; Zhang, Z.; Yan, X.; Chai, J.; Ren, Z.; Zheng, G.; Liu, H. Graft-union development: A delicate process that involves cell-cell communication between scion and stock for local auxin accumulation. J. Exp. Bot. 2012, 63, 4219-4232. [CrossRef] [PubMed]

29. Iwase, A.; Mitsuda, N.; Koyama, T.; Hiratsu, K.; Kojima, M.; Arai, T.; Inoue, Y.; Seki, M.; Sakakibara, H. Report the AP2 / ERF transcription factor WIND1 controls cell dedifferentiation in Arabidopsis. Curr. Biol. 2011, 21, 508-514. [CrossRef] [PubMed]

30. Immanen, J.; Nieminen, K.; Smolander, O.-P.; Kojima, M.; Alonso Serra, J.; Koskinen, P.; Zhang, J.; Elo, A.; Mähönen, A.P.; Street, N.; et al. Cytokinin and auxin display distinct but interconnected distribution and signaling profiles to stimulate cambial activity. Curr. Biol. 2016, 26, 1990-1997. [CrossRef]

31. Ikeuchi, M.; Iwase, A.; Rymen, B.; Lambolez, A.; Kojima, M.; Takebayashi, Y.; Heyman, J.; Watanabe, S.; Seo, M.; De Veylder, L.; et al. Wounding triggers callus formation via dynamic hormonal and transcriptional changes. Plant Physiol. 2017, 175, 1158-1174. [CrossRef]

32. Tiedemann, R. Graft union development and symplastic phloem contact in the heterograft Cucumis sativus on Cucurbita ficifolia. J. Plant Physiol. 1989, 134, 427-440. [CrossRef]

33. Aloni, R. Role of auxin and sucrose in the differentiation of sieve and tracheary elements in plant tissue cultures. Planta 1980, 150, 255-263. [CrossRef] [PubMed]

34. Donner, T.J.; Sherr, I.; Scarpella, E. Regulation of preprocambial cell state acquisition by auxin signaling in Arabidopsis leaves. Development 2009, 136, 3235-3246. [CrossRef]

35. Sachs, T. The role of the root in the induction of xylem differentiation in peas. Ann. Bot. 1968, 32, 391-399. [CrossRef]

36. Sachs, T. The control of the patterned differentiation of vascular tissues. Adv. Bot. Res. 1981, 9, 151-262.

37. Biedroń, M.; Banasiak, A. Auxin-mediated regulation of vascular patterning in Arabidopsis thaliana leaves. Plant Cell Rep. 2018, 37, 1215-1229. [CrossRef]

38. van de Pol, P.A.; Joosten, M.H.A.J.; Keizer, H. Stenting of roses, starch depletion and accumulation during the early development. Acta Hortic. 1986, 189, 51-60. [CrossRef]

39. Asahina, M.; Azuma, K.; Pitaksaringkarn, W.; Yamazaki, T.; Mitsuda, N.; Ohme-Takagi, M.; Yamaguchi, S.; Kamiya, Y.; Okada, K.; Nishimura, T.; et al. Spatially selective hormonal control of RAP2.6L and ANAC071 transcription factors involved in tissue reunion in Arabidopsis. Proc. Natl. Acad. Sci. USA 2011, 108, 16128-16132. [CrossRef]

40. Marsch-Martínez, N.; Franken, J.; Gonzalez-Aguilera, K.L.; de Folter, S.; Angenent, G.; Alvarez-Buylla, E.R. An efficient flat-surface collar-free grafting method for Arabidopsis thaliana seedlings. Plant Methods 2013, 9, 14. [CrossRef] [PubMed]

41. Wetmore, R.H.; Rier, J.P. Experimental induction of vascular tissues in callus of angiosperms. Am. J. Bot. 1963, 50, 418. [CrossRef] 
42. Herrero, J. Studies on compatible and incompatible graft combinations with special reference to hardy fruit trees. J. Hortic. Sci. 1951, 26, 186-237. [CrossRef]

43. Kollmann, R.; Glockmann, C. Studies on graft unions III. On the mechanism of secondary formation of plasmodesmata at the graft interface. Protoplasma 1991, 165, 71-85. [CrossRef]

44. Moore, R.; Walker, D.B. Studies of vegetative compatibility-incompatibility in higher plants. I. A structural study of a compatible autograft in Sedum telephoides (Crassulaceae). Am. J. Bot. 1981, 68, 820-830. [CrossRef]

45. Moore, R.; Walker, D.B. Studies of vegetative compatibility-incompatibility in higher plants. II. A structural study of an incompatible heterograft between Sedum telephoides (Crassulaceae) and Solanum pennellii (Solanaceae). Am. J. Bot. 1981, 68, 831-842. [CrossRef]

46. Asahina, M.; Iwai, H.; Kikuchi, A.; Yamaguchi, S.; Kamiya, Y.; Kamada, H.; Satoh, S. Gibberellin produced in the cotyledon is required for cell division during tissue reunion in the cortex of cut cucumber and tomato hypocotyls. Plant Physiol. 2002, 129, 201-210. [CrossRef]

47. Sala, K.; Karcz, J.; Rypień, A.; Kurczyńska, E.U. Unmethyl-esterified homogalacturonan and extensins seal Arabidopsis graft union. BMC Plant Biol. 2019, 19, 151. [CrossRef]

48. Pitaksaringkarn, W.; Matsuoka, K.; Asahina, M.; Miura, K.; Sage-Ono, K.; Ono, M. XTH20 and XTH19 regulated by ANAC071 under auxin flow are involved in cell proliferation in incised Arabidopsis inflorescence stems. Plant J. 2014, 80, 604-614. [CrossRef]

49. Notaguchi, M.; Kurotani, K.I.; Sato, Y.; Tabata, R.; Kawakatsu, Y.; Okayasu, K.; Sawai, Y.; Okada, R.; Asahina, M.; Ichihashi, Y.; et al. Cell-cell adhesion in plant grafting is facilitated by $\beta-1,4$-glucanases. Science 2020, 369, 698-702. [CrossRef]

50. Yeoman, M. Cellular reconigtion systems in grafting. In Cellular Interactions; Linskens, H.F., Heslop-Harrison, J., Eds.; Springer: Berlin, Germany, 1984; pp. 453-472.

51. Nühse, T.S. Cell wall integrity signaling and innate immunity in plants. Front. Plant Sci. 2012, 3, 280. [CrossRef] [PubMed]

52. Savatin, D.V.; Gramegna, G.; Modesti, V.; Cervone, F. Wounding in the plant tissue: The defense of a dangerous passage. Front. Plant Sci. 2014, 5, 470. [CrossRef] [PubMed]

53. Hawkins, S.; Boudet, A. Wound-induced lignin and suberin deposition in a woody angiosperm (Eucalyptus gunnii Hook.): Histochemistry of early changes in young plants. Protoplasma 1996, 191, 96-104. [CrossRef]

54. Schneider, H. Deposition of wound gum, callose, and suberin as responses to diseases and wounding of citrus. Bull. Socete Bot. Fr. Actual. Bot. 1980, 127, 143-150. [CrossRef]

55. Biggs, A.R.; Miles, N.W. Suberin deposition as a measure of wound response in peach bark. HortScience 1985, $20,903-905$.

56. Rittinger, P.A.; Biggs, A.R.; Peirson, D.R. Histochemistry of lignin and suberin deposition in boundary layers formed after wounding in various plant species and organs. Can. J. Bot. 1987, 65, 1886-1892. [CrossRef]

57. O'Brien, J.A.; Daudi, A.; Butt, V.S.; Bolwell, G.P. Reactive oxygen species and their role in plant defence and cell wall metabolism. Planta 2012, 236, 765-779. [CrossRef] [PubMed]

58. Leeuw, G.T.N. Deposition of lignin, suberin and callose in relation to the restriction of infection by Botrytis cinerea in ghost spots of tomato fruits. J. Phytopathol. 1985, 112, 143-152. [CrossRef]

59. Norday, T.; Shem, E.; Huat, J. Impacts of temperature and rootstocks on tomato grafting success rates. HortScience 2020, 55, 136-140. [CrossRef]

60. Zhao, Y.; Dong, C.J.; Shang, Q. Healing responses of tube grafted tomato plug seedlings under different night temperatures. Acta Bot. Boreali-Occident. Sin. 2015, 35, 493-499. 